\title{
TOXICITY OF SOURSOP EXTRACTS TO DIAMONDBACK MOTH
}

\section{TOXICIDADE DE EXTRATOS DE GRAVIOLA SOBRE A TRAÇA-DAS-CRUCÍFERAS}

\author{
Roseane Cristina Predes TRINDADE ${ }^{1}$; Ismael Barros GOMES ${ }^{2}$; \\ Eurico Eduardo Pinto de LEMOS ${ }^{3}$; Antônio Euzébio Goulart SANT'ANA ${ }^{4}$ \\ 1. Professora, Doutora, Laboratório de Entomologia: controle alternativo de pragas, Centro de Ciências Agrárias, Universidade Federal \\ de Alagoas - UFAL, Rio Largo, AL, Brasil, rcpt@ @eca.ufal.br; 2. Mestre em Proteção de Plantas, Centro de Ciências Agrárias, \\ Universidade Federal de Alagoas - UFAL, Rio Largo, AL, Brasil; 3. Professor, PhD, Laboratório de Biotecnologia Vegetal, Centro de \\ Ciências Agrárias, Universidade Federal de Alagoas - UFAL, Rio Largo, AL, Brasil; Professor, Doutor, Laboratório de Pesquisa de \\ Produtos Naturais , Centro de Ciências Agrárias, Universidade Federal de Alagoas - UFAL, Rio Largo, AL, Brasil.
}

\begin{abstract}
This study aimed to evaluate the effects of three solvent extractors (water, ethanol and hexane) of grounded seeds of soursop, Annona muricata L. (Annonaceae), in the mortality, biology and oviposition of Plutella xylostella L. (Lepidoptera: Plutellidae). The results showed that the $\mathrm{LC}_{50}$ and $\mathrm{LC}_{99}$ were 0.0133 and $0.084 \%, 0.025 \%$ and $0.196 \%, 2.33$ and $35.22 \%$ for the ethanolic, hexanic and aqueous extracts, respectively. The organic extracts affected only the larval phase and reduced viability in more than $60 \%$, but did not affect pupal stage of the remaining larvae. Furthermore, the ethanolic extract at lethal concentraction also affected negatively the embryonic phase. The results lead to the conclusion that the ethanolic extract of soursop grounded seeds is a viable alternative to control diamondback moth on vegetables.
\end{abstract}

KEYWORDS: Plutella xylostella. Annona muricata. Biology. $\mathrm{LC}_{50}$. Persistence.

\section{INTRODUCTION}

The increase in the demand for healthier foods and the problems resulting from the use of chemical pesticides has contributed to the interest of the use of natural products that show reduced risks to human health, to the environment and are more selective (MENEZES, 2005).

Several plant families have drawn attentio The Annonaceae family has been gaining prominence since 1980, due to the presence of substances called acetogenins in plant organs, a class of secondary matabolites that presents a broad biological activity, which includes their insecticidal action $\mathrm{n}$ as promising sources of organic compounds with insecticidal action among them are: Annonaceae, Solanaceae and Meliaceae. These families have been selected to be studied for the following reasons: 1) they possess compounds of different chemical groups for insect control; 2) they are frequent families in the tropics and are cultivated in various regions; 3) researches have shown biological activity against insects and highlighted them as potential plants to produce botanical insecticides (CASTILLO-SÁNCHEZ et al., 2010).

The Annonaceae family has been gaining prominence since 1980, due to the presence of substances called acetogenins in plant organs, a class of secondary matabolites that presents a broad biological activity, which includes their insecticidal action (OCAMPO; OCAMPO, 2006).
Isman and Seffrin (2014), claim that the Annonaceae family has the potential to originate bionatural products and the species Asimina triloba L., Annona muricata L. and Annona squamosa L. have been most frequently examined for their insecticidal effects. Extracts from Annonaceae have been tested for control of Lepidoptera, Hymenoptera, Coleoptera and Diptera, especially against Spodoptera frugiperda (J.E. Smith) (Lepidoptera: Noctuidae), Plutella xylostella L. (Lepidoptera: Plutellidae), Aedes aegypti L. (Diptera: Culicidae), and pests of stored grains. Crude extracts from seeds, leaves, and fruits are the most frequently tested as biopesticides.

The diamondback moth, $P$. xylostella is a highly migratory insect and has been considered as the main pest species of Brassicaceae plants and its great limiting factor in the world (ZALUCKI et al., 2012). It causes serious damage to the plants, depreciating the product and reducing yield (CASTELO BRANCO et al., 2001).

Optimization studies of extraction methods to obtaining active principles are increasingly frequent, since the vegetable matrix is quite complex and the metabolites, with some exceptions, occur in lower concentrations relative to the dry weight of the plant (JADHAV et al., 2009, BIMAKRA et al., 2011). To that extent, different techniques, solvents and extraction time are tested in order to assess the influence of these variables on the content and chemical composition of the extracts 
(SPIGNO; TRAMELLI; DE FAVERI, 2007; ASPÉ; FERNÁNDEZ, 2011).

The present work aimed to evaluate the effects of grounded soursop (A. muricata) seed extracts on the biology of diamondback moth $(P$. xylostella).

\section{MATERIAL AND METHODS}

\section{Insect rearing}

The initial population of $P$. xylostella was obtined on the entomology laboratory of the Universidade Federal Rural de Pernambuco and maintained at $26 \pm 2^{\circ} \mathrm{C}, 60 \pm 10 \%$ relative air humidity and $12 \square$ hour photoperiod, according to the methodology established by Medeiros et al. (2003), and fed with leaves of cabbage, Brassica oleracea var. acephala DC. (Brassicaceae) cv. Georgia, produced in beds containing commercial substrate Bioplant ${ }^{\mathrm{TM}}$ inside a green house. The experiments started from the third generation of insects in the laboratory.

\section{Preparation of soursop seed extracts}

Soursop seeds were obtained from the fresh waste of a processing fruit pulp plant in Anadia, AL, Brazil, in 2012 . The seeds $(2.5 \mathrm{~kg})$ were washed to remove most of pulp and air-dried at $48^{\circ} \mathrm{C}$ for 48 hours, triturated in a forage grinding mill (mesh size $2.5 \mathrm{~mm}$ ) to yield a fine, uniform powder, and stored at $4 \pm 2^{\circ} \mathrm{C}$.

To prepare the hexanic extract, $2.3 \mathrm{~kg}$ of the seeds powder were used with 5L of hexane Panreac grade HPLC in a percolator for a period of 72 hours. After that, the same seed powder was used for the ethanolic extraction using $4.6 \mathrm{~L}$ of ethanol for three periods of 72 hours. The excess of solvents was removed under reduced pressure at $50^{\circ} \mathrm{C}$; and the crude residues were placed in desiccators to remove any remaining moisture and stored at $4 \pm 2^{\circ} \mathrm{C}$.

To prepare the aqueous extract, $1.0 \mathrm{~kg}$ the seed powder was extracted with $2 \mathrm{~L}$ of water in a percolator for $48 \mathrm{~h}$ and diluted to the desired concentrations.

Determination of lethal concentrations of soursop seed extracts and the effect of $\mathrm{LC}_{50}$ on Plutella xylostella biology

It was conducted a test to establish the $\mathrm{LC}_{50}$ and $\mathrm{LC}_{99}$ using the concentrations $0.0,1.25,2.5,0.5$, 10.0 and $20.0 \%$ for the aqueous extract, $0.0,0.01$, $0.05,0.1$ and $0.2 \%$ for the hexanic and ethanolic extracts plus 1\% DMSO (Dimethyl sulphoxide) in distilled water.
Twenty discs of $8 \mathrm{~cm}$ in diameter were cut from cabbage leaves including midrib and immersed separately for $30 \mathrm{~s}$ in the different solutions, and control discs were immersed only in $1 \%$ DMSO in distilled water. The discs were left to dry out at room temperature of $26 \pm 2^{\circ} \mathrm{C}$ for 2 hours, after which they were placed in individual Petri dishes together with 12 newly hatched larvae. The twenty dishes were sealed with PVC film and maintained at room temperature of $26 \pm 2^{\circ} \mathrm{C}, 60 \pm 10 \%$ relative air humidity and $12 \mathrm{~h}$ of photophase. As the cabbage discs became yellow, or were consumed by the larvae, they were replaced daily by newly treated discs. Larval mortality was evaluated on the third day of the experiment, when larvae left the leaf mines, and daily until the pupal stage.

In the insect biology experiment, to $\mathrm{LC}_{50}$ (0.02 and 0.01 to hexanic and etanolic, respectively), when the larvae turned into pupae, they were individually placed in glass tubes $(25 \mathrm{x}$ $85 \mathrm{~mm}$ ) in a variable number according to the treatment until adult emergence and the duration and viability of larval, pupal stages and adults longevity were evaluated. A control solution of distilled water and DMSO (1\%) was used. The extracts were also compared with the application of the insecticide deltamethrin as a positive control $\left(\right.$ Decis $\left.^{\circledR} 25 \mathrm{EC}\right)$ in a commercial dosage $(30 \mathrm{~mL} / 100$ L).

The experiment was carried out in a completely randomized design with six treatments to aqueous extract, five treatments to hexanic extracts and five treatments to etanolic extracts with five replicates to determine the lethal concentrations. To determine the $\mathrm{LC}_{50}$ and $\mathrm{LC}_{99}$, it was used Probit analysis performed with the software SAS version 9.0 (SAS Institute, 2003).

In biology experiment was carried out in a completely randomized design with four treatments $\left(\mathrm{LC}_{50}\right.$ hexanic extract, $\mathrm{LC}_{50}$ ethanolic extract, control and positive control), the data were submitted to analysis of variance and means were compared by Tukey test, at $5 \%$ of probability. The data of the larval viability were transformed into $\sqrt{\mathrm{x}}+0.5$, with Assistat version 7.5 software (SILVA; AZEVEDO, 2009).

As the aqueous extracts showed lower efficiency, requiring a large amount of plant material to obtain the lethal concentration, the following experiments were performed only with the organic extracts (hexanic and ethanolic). 
Evaluaton of the effect of extracts of soursop seeds in the embryonic stage of Plutella xylostella

Two couples of the insect up to $12 \mathrm{~h}$ of age were selected for mating and later oviposition and placed in plastic cages identical to the ones used in the insect rearing with one leaf disc per cage. After 24 hours of mating, the oviposition discs were removed from the cages by selecting those presenting a minimum of 20 eggs. The collected eggs were immersed in hexanic and ethanolic extracts in their respectively $\mathrm{LC}_{50}$ and $\mathrm{LC}_{99}(0.02$ and $0.19 \mathrm{~mL} \cdot \mathrm{mL}^{-1}, 0.01$ and $0.08 \mathrm{~mL} \cdot \mathrm{mL}^{-1}$ ) distilled water for the control, and chemical insecticide deltamethrin as a positive control (Decis ${ }^{\circledR} 25$ EC) in a commercial dosage $(30 \mathrm{~mL} / 100 \mathrm{~L})$.

The experiment was carried out in a completely randomized design with six treatments (control, chemical, hexanic and ethanolic extracts in $\mathrm{LC}_{50}$ and $\mathrm{LC}_{99}$ ) and five replicates each having a minimum of 20 eggs of the pest. For eight days it was evaluated the number of larvae hatched. Data were submitted to analysis of variance and means were compared by Tukey test, at $5 \%$ of probability with Assistat version 7.5 software (SILVA; AZEVEDO, 2009).

\section{RESULTS AND DISCUSSION}

Determination of lethal concentrations of
extracts of soursop seeds to Plutella xylostella
Estimated values of the lethal
concentrations were 0.01 and $0.08 \% ; 0.02$ and
$0.19 \% ; 2.33$ and $35.22 \%$, for $\mathrm{CL}_{50}$ and $\mathrm{CL}_{99}$ of the
ethanolic, hexanic and aqueous extract, respectively
(Table 1).
Generally aqueous extracts of plants require
high concentrations to have an efficient insecticidal
activity. This can be well exemplified in the work of
Torres et al. (2006) that shows a concentration of
0.6\% of aqueous extracts of neem (Azadirachta
indica A. Juss) for the $\mathrm{LC}_{50}$ of Plutella xylostella.

Table 1. Mortality evaluation (Probit Analysis) for aqueous, ethanolic and hexane extracts of Annona muricata seed.

\begin{tabular}{lccllll}
\hline Extract & $\mathbf{G L}$ & $\mathbf{n}^{\mathbf{1}}$ & $\begin{array}{l}\mathbf{L} \mathbf{C}_{\mathbf{5 0}}\left(\mathbf{I C}_{\mathbf{9 5}}\right)^{\mathbf{3}} \\
(\mathbf{m L} \cdot \mathbf{m L}\end{array}$ & $\mathbf{L C}_{\mathbf{9 9}}\left(\mathbf{I C}_{\mathbf{9 5} \%}\right)^{\mathbf{3}}\left(\mathbf{m L} \cdot \mathbf{m L} \mathbf{L}^{-\mathbf{1}}\right)$ & $\mathbf{X}^{\mathbf{2}}$ & $\boldsymbol{p}^{\mathbf{4}}$ \\
\hline Aqueous extract & 4 & 50 & $2.33(0.61-4.17)$ & $35.22(11.71-11404)$ & 1.03 & 0.59 \\
Hexanic extract & 5 & 60 & $0.02(0.01-0.03)$ & $0.19(0.10-0.88)$ & 2.12 & 0.82 \\
Ethanolic extract & 5 & 60 & $0.01(0.01-0.02)$ & $0.08(0.04-0.53)$ & 0.38 & 0.98 \\
\hline
\end{tabular}

${ }^{*}$ SE: Standart erro; LC: lethal concentration; $\mathrm{X}^{2}$ : Chi-square; ${ }^{1} \mathrm{DF}$ : Degrees of freedom; ${ }^{2} \mathrm{n}$ : Number of insects used in the test; ${ }^{3} \mathrm{CI}$ : Confidence interval; ${ }^{4} P$ : probability $>0.05$.

The lower efficiency of aqueous extracts of plant organs containing organic compounds with insecticidal action was also observed in the work of Gonzalez-Esquinca et al. (2012), when comparing aqueous and ethanolic extracts of species of Annonaceae on larvae of the fruit fly, Anastrepha ludens (Loew) (Diptera: Tephritidae). They have found that the values of lethal concentrations of the organic extracts were lower than those of the aqueous extract. Similarly, in the present work, both ethanolic and hexanic extracts showed lethal concentrations lower than aqueous extract.

The necessity of higher concentrations of the hexanic extract compared to ethanolic extract to promote insect mortality has also been reported elsewhere as highly nonpolar extracts are less efficient than those with intermediate polarity, such as ethanol (ROEL et al., 2000). Borges et al. (2007) reported, when comparing extracts prepared with different solvents in order to increase the polarity, that solvents of lower polarity showed poorer activitiy.

\section{Effect of $\mathrm{LC}_{50}$ of extracts of soursop seeds on the biology of Plutella xylostella}

The organic extracts of soursop seeds and chemical insecticide treatments showed about 30\% of larval viability of $P$. xylostella, differing on the Tukey test $(\mathrm{F}=14.27, \mathrm{p}<0.001)$ from the control, which showed $80 \%$ of the larval viability. These treatments showed more expressive mortality in newly-hatched larvae, making them unable to reach the pupal stage (Table 2).

The action of plant extracts on the reduction of larval viability of $P$. xylostella was also reported by other authors, as in Silva et al. (2007) where 
extracts of different species of Croton spp. (Euphorbiaceae) were effective for controlling $P$. xylostella. They showed that Croton jacobinensis (leaf and stem), Croton rhamnifolius (leaf and stem), Croton sellowii (leaf and stem) and Croton micans (leaf) in highest concentrations resulted larval mortalities of 95; 100; 100 and 95\%, respectively. Jesus et al. (2011) reported that larvae fed on cabbage leaves containing the extract of neem showed high mortality with few larvae reaching the pupal stage, but also in the extract of Sapindus saponaria (Sapindaceae) (soap welded) viability was only $40 \%$. Souza et al. (2011) evaluating the hexanic extract at $0.5 \%$ of Jatropha curcas L., observed that the larval viability was also affected, as only $11 \%$ of the larvae reached the pupal stage, much lower than the control with $80 \%$.

Table 2. Mean \pm SD of viability and duration of larval and pupal stages of Plutella xylostella treated with organic extracts of the seed of Annona muricata

\begin{tabular}{|c|c|c|c|c|}
\hline & $\begin{array}{l}\text { Larval viability }(\%) \pm \\
\mathrm{SD}^{*}\end{array}$ & $\begin{array}{l}\text { Larval duration (days) } \\
\pm \mathrm{SD}\end{array}$ & $\begin{array}{l}\text { Pupal viability }(\%) \pm \\
\text { SD }\end{array}$ & $\begin{array}{l}\text { Pupal duration (days) } \\
\pm \text { SD }\end{array}$ \\
\hline Control & $81.60 \pm 09.45 \mathrm{a}$ & $7.10 \pm 0.45 \mathrm{a}$ & $83.80 \pm 12.86 \mathrm{~ns}$ & $3.82 \pm 0.16 \mathrm{~ns}$ \\
\hline Chemical & $38.30 \pm 19.42 b$ & $4.80 \pm 1.41 \quad b$ & $70.80 \pm 32.21 \mathrm{~ns}$ & $3.18 \pm 1.20 \mathrm{~ns}$ \\
\hline Hexane & $38.30 \pm 23.63 \mathrm{~b}$ & $4.80 \pm 1.32 b$ & $82.90 \pm 24.86 \mathrm{~ns}$ & $3.75 \pm 0.35 \mathrm{~ns}$ \\
\hline Ethanol & $31.60 \pm 21.44 \quad b$ & $5.00 \pm 1.78 \mathrm{~b}$ & $58.30 \pm 37.88 \mathrm{~ns}$ & $2.98 \pm 1.61 \mathrm{~ns}$ \\
\hline $\mathrm{CV} \%$ & 29.42 & 24.52 & 31.3 & 28.73 \\
\hline
\end{tabular}

$\mathrm{CV}=$ Coefficient of variation

According to Aguiar Menezes (2005), neem extracts act as insecticides, repellents or as antifeedant, inhibiting the insect to start feeding. These effects may also have occurred with larvae of P. xylostella when fed with cabbage leaves treated with organic extracts of soursop seeds or chemical insecticide, causing high mortality in an early stage of the insect.

The larval duration was statistically different by the Tukey test $(\mathrm{F}=6.16, \mathrm{p}<0.001)$, as can be seen in Table 2. The treatments with ethanolic and hexanic extracts and chemical insecticide differed from the control, but not among them.

The shorter larval duration may have occurred as a consequence of the higher mortality of larvae in early development. Different results are usually reported in studies with plant insecticides, as they show a tendency to extend the larval stage (TORRES et al., 2006; SILVA et al., 2007; SOUZA et al., 2011; JESUS et al., 2011) by inhibiting or deterring feeding and other actions (MORDUE (LUNTZ); MORGAN; NISBET, 2005). Another hypothesis, reported by Rodrigues et al. (2008), is that the reduction of this phase could be a form used by the pest to compensate inadequate food supply, passing to the next stage in a shorter time.

According to Torres et al. (2006), the prolongation of the larval stage and larval mortality of $P$. xylostella by application of plant extracts is very important in field condition, as it will increase the time of exposure of pests to natural enemies and the average time of each pest generation, reducing the growth of their population. However, the insecticidal action presented in this work by organic extracts of soursop was far more efficient, since they acted in the early stages of the pest studied, reducing their attack and contributing to the decrease in subsequent populations (RODRIGUEZ; VENDRAMIM, 1996). In the present work, the shortening of the larval stage also demonstrates a favorable factor as the caterpillars changed phase without a sufficient amount of nutrients, which resulted in higher larval infeasibility.

The duration and pupal viability did not differ between treatments and the control. This result, according to various works (ROEL et al., 2000; SILVA et al., 2007; MATOS et al., 2010), showed that the main insecticidal effects of the extracts were in the larval stage. Torrecillas $\mathrm{e}$ Vendramim (2001) studying the effect of aqueous 
extract of $T$. pallida and maize genotypes on the development of Spodoptera frugiperda (J.E. Smith, 1797) (Lepidoptera: Noctuidae), observed that the largest effects observed in the larval stage were given by the fact that is at that stage the insect feeds, making it more exposed to potential allelochemicals.

The pupal duration did not show significant differences, lasting on average, three days (Table 2), suggesting that the insect can be affected in their vital functions, which reflects the mortality parameter, but not regarding the development time of the pupal stage (CAMPOS; BOIÇA JUNIOR, 2012).

Effect of extracts of soursop seeds in the embryonic stage of Plutella xylostella

The embryonic stage of P. xylostella did not show significant difference at $1 \%$ probability for the Tukey test $(\mathrm{F}=8.77, \mathrm{p}<0.001)$ among treatments. Only the ethanolic treatment $\mathrm{LC}_{99}$ differed statistically from the control (Table 3).

Table 3. Viability (\%) \pm SD of eggs of Plutella xylostella treated with organic extracts of the seed of Annona muricata

\begin{tabular}{ll} 
Treatments & \% hatched caterpillars \pm SD* \\
\hline Control & $98.4 \pm 1.93 \mathrm{a}$ \\
Chemical & $95.4 \pm 9.01 \mathrm{a}$ \\
Hexane $\mathrm{LC}_{50}{ }^{* * *}$ & $80.5 \pm 16.5 \mathrm{ab}$ \\
Hexane $\mathrm{LC}_{99}{ }^{* * *}$ & $65.5 \pm 5.86 \mathrm{ab}$ \\
Ethanol $\mathrm{LC}_{50}$ & $82.1 \pm 10.6 \mathrm{ab}$ \\
Ethanol $\mathrm{LC}_{99}$ & $58.4 \pm 12.5 \mathrm{~b}$ \\
\hline $\mathrm{CV}^{* * *}$ & 13.11 \\
\hline$=$ Standart Deviation; Means followed by the same letter in columns are not statistically different by Tukey test; $(\mathrm{P} \leq 0,05)$
\end{tabular}

The effect of plant extracts on embryonary stage of lepidoptera is little known, due to low or no effect of these extracts on the eggs. This inefficiency of the extracts may be related to the fact that the egg can have a lipid layer on the inside of the chorion, which would retain the toxic substances of the extracts. Therefore, the ovicidal action of the extracts has interfered with its action by the shape and composition of eggs (SALKELD; SMITH, 1966).

The effects of plant extracts on the survival of eggs of Lepidoptera are also little known, especially the ovicidal action of bioactive compounds (TRINDADE et al., 2000). Machado; Silva; Oliveira (2007) noted that the ovicidal effect may vary according to the insect species and the characteristics of the substances used. However, the same author mentions that plants with insecticidal activity cause low or no effect on eggs. This can be seen in a experiment with the different aqueous extracts of $10 \%$ Chenopodium ambrosioides (Linnaeus) (Amaranthaceae), Corymbia citriodora (Hill \& Johnson) (Mrytaceae), Chrysanthemum leucanthemum (Linnaeus) (Asteraceae) and $A$. indica on the percentage of hatched larvae of $S$. frugiperda, that showed no ovicidal action (MAZZONETTO et al., 2013).

Torres et al. (2006) obtained similar data in embryonary stage of $P$. xylostella when eggs were submitted to three plant extracts in lethal and sublethal concentrations. In this experiment, the ovicidal action increased with the concentration of the extracts. It was also noticed that the extract concentration also influenced the embryo, as the lethal concentration of ethanolic extract was more efficient than the sublethal concentration $\left(\mathrm{LC}_{50}\right)$.

Biermann et al. (2009) evaluated various plant extracts at a concentration of $10 \%$ and also neem commercial products at $1 \%$ and $5 \%$ on eggs of Ascia monuste orseis (Lepidoptera: Pieridae). Their results showed inviability of the eggs up to $100 \%$ for Nicotiana spp. extracts and $94 \%$ for commercial products.

\section{CONCLUSIONS}

The solvent used in the extraction process influences the biological activity of $P$. xylostella; 
The ethanolic extract of soursop seeds has the smallest lethal concentration;

The larval stage of $P$. xylostella is the most affected by the extracts;

The ethanolic extract at the lethal concentration is efficient to negatively affect the embryonic stage of $P$. xylostella.

\section{ACKNOWLEDGMENTS}

The authors would like to thank the financial support from the Foundation for Research Support of the State of Alagoas (FAPEAL) and the scholarship granted to the first author.

RESUMO: O presente trabalho teve como objetivo avaliar o efeito de extratos de sementes de graviola, Annona muricata L. (Annonaceae) obtidos com diferentes solventes sobre Plutella xylostella L. (Lepidoptera: Plutellidae). Foram estimadas as concentrações letais de três solventes extratores (água, hexano e etanol) e seus efeitos na biologia e oviposição. Os valores estimados das concentrações letais foram de 0,013 e 0,084\%; 0,025 e 0,196\%; 2,33 e 35,22\%, para as $\mathrm{CL}_{50}$ e $\mathrm{CL}_{99}$ do extrato etanólico, hexânico e aquoso, respectivamente. Os extratos orgânicos afetaram apenas a fase larval e reduziu a viabilidade em mais de $60 \%$, mas não afetou a fase pupal das lagartas remanescentes. Além disso, o extrato etanólico na concentração letal se mostrou eficiente afetando negativamente a fase embrionária. Conclui-se que o extrato etanólico da graviola é uma alternativa viável no controle da traça.

PALAVRAS-CHAVE: Plutella xylostella. Annona muricata. Biologia. CL 50 . Persistência.

\section{REFERENCES}

AGUIAR MENEZES, E. L. M. Inseticidas Botânicos: Seus Princípios Ativos, Modo de Ação e Uso Agrícola. Seropédica/RJ: Embrapa Agrobiologia. 58p. (Embrapa Agrobiologia. Documentos 205). 2005.

ASPÉ, E.; FERNÁNDEZ, K. The effect of different extraction techniques on extraction yield, total phenolic, and anti-radical capacity of extracts from Pinus radiata Bark. Industrial Crops and Products, v. 34, n. 1, p. 838-844, 2011. https://doi.org/10.1016/j.indcrop.2011.02.002

BIERMANN, A. C. S.; PONCIO, S.; ROSALINO, P. K.; RIBEIRO, L. P .; DEQUECH, S. T. B. Ação de extratos vegetais sobre posturas de Ascia monuste orseis (Lepidoptera: Pieridae). In: ENCONTRO INTERNACIONAL DE PRODUÇÃO CIENTIFICA CESUMAR, 6, 2009. Anais... Maringá: CESUMAR (Centro Universitário de Maringá), 2009. p. 1- 4. Disponível em:

http://www.cesumar.br/epcc2009/anais/pedro_krauspenhar_rosalino.pdf. Acesso em 30 jun 2014.

BIMAKRA, M.; RAHMAN, R. A; TAIP, F. S.; GANJLOO, A.; SALLEH, L. M; SELAMAT, J.; HAMID, A.; ZAIDUL, I. S. M. Comparison of different extraction methods for the extraction of major bioactive flavonoid compounds from spearmint (Mentha spicata L.) leaves. Food and Bioproducts Processing, v. 89, p. 67-72, 2011. https://doi.org/10.1016/j.fbp.2010.03.002

BORGES, L. R.; ASTOLFI, V.; MOSSI, A. J.; CANSIAN, R. L. Determinação de Atividades Biológicas em Extratos de Carqueja (Baccharis trimera (Less). D.C.). In: CONGRESSO DE ECOLOGIA DO BRASIL, 8, 2007. Anais... Caxambu: Sociedade de Ecologia do Brasil, 2007. p. 1-2. Disponível em: http://www.sebecologia.org.br/viiiceb/pdf/1921.pdf. Acesso em: 30 jun. 2014.

CAMPOS, A. P.; BOIÇA JUNIOR, A. L. Lagartas de Spodoptera frugiperda (J. E. SMITH) (Lepidoptera: Noctuidae) submetidas a diferentes concentrações de óleo de nim. Revista Brasileira de Milho e Sorgo, v. 11, p. 137-144, 2012. https://doi.org/10.18512/1980-6477/rbms.v11n2p137-144

CASTELO BRANCO, M.; FRANÇA, F. H.; MEDEIROS, M. A.; LEAL, J. G. T. Uso de inseticidas para o controle da traça-do-tomateiro e traça-das-crucíferas: um estudo de caso. Horticultura Brasileira, v. 19, n. 1, p. 60-63, 2001. https://doi.org/10.1590/S0102-05362001000100012 
CASTILlO-SÁNCHEZ, L. E.; JIMÉNEZ-OSORNIO, J. J.; DELGADO-HERRERA, M. A. Secondary metabolites of the annonaceae, solanaceae and meliaceae families used as biological control of insects. Tropical and Subtropical Agroecosystems, v. 12, p. 445-462, 2010.

GONZÁLEZ-ESQUINCA, A. R.; LUNA CAZÁRES, L. M.; SCHLIE GUZMÁN, M. A.; CHACÓN C., I. L. C.; LAGUNA HERNÁNDEZ, G.; FLORES BRECEDA, S.; MONTOYA GERARDO, P.. In vitro larvicial evaluation of Annona muricata L., A. diversifolia Saff. and A. lutescens Saff. extracts against Anastrepha ludens larvae (Diptera, Tephritidae). Interciência, v. 37, p. 284-289, 2012.

ISMAN, M. B.; SEFFRIN, R. Natural insecticides from the Annonaceae: a unique example for developing biopesticides. In: Advances in Plant Biopesticides, p. 21-33, 2014. https://doi.org/10.1007/978-81-322-20060_2

JADHAV, D.; REKHA, B. N.; PARAG, R. G.; VIRENDRA, K. R. Extraction of vanillin from vanilla pods: a comparison study of conventional soxhlet and ultrasound assisted extraction. Journal of Food Engineering, v. 93, p. 421-426, 2009. https://doi.org/10.1016/j.jfoodeng.2009.02.007

JESUS, F. G.; PAIVA, L. A.; GONÇALVES, V. C.; MARQUES, M. A.; BOIÇA JUNIOR, A. L. Efeito de plantas inseticidas no comportamento e biologia de Plutella xylostella (Lepidoptera: Plutellidae). Arquivo do Instituto de Biologia, v. 78, p. 279-285, 2011.

MACHADO, L. A.; SILVA, V. B.; OLIVEIRA, M. M. Uso de extratos vegetais no controle de pragas em horticultura. O Biológico, v. 69, p. 103-106, 2007.

MATOS, C. H. C.; OLIVEIRA, C. R. F.; SANTOS, M. P. F.; FERRAZ, C. S. Utilização de modelos didáticos no ensino de entomologia. Revista de Biologia e Ciências da terra, v. 9, p. 37-39, 2010.

MAZZONETTO, F.; CORADINI, F.; CORBANI, R. Z.; DALRI, A. B. Ação de inseticidas botânicos sobre a preferência alimentar e sobre posturas de Spodoptera frugiperda (J.E. Smith) (Lepidoptera: Noctuidae) em milho. EntomoBrasilis, v. 6, p. 34-38, 2013. https://doi.org/10.12741/ebrasilis.v6i1.261

MEDEIROS, P. T.; DIAS, J. M. C. S.; MONNERAT, R. G.; SOUZA, N. R. Instalação e manutenção de criação massal da traça-dascrucíferas (Plutella xylostella). Brasília: Embrapa Recursos Genéticos e Biotecnologia, 4p. (Embrapa Recursos Genéticos e Biotecnologia. Circular Técnica, 29). 2003.

MENEZES, E. L. A. Inseticidas botânicos: seus princípios ativos, modo de ação e uso agrícola. Seropédica, Rio de Janeiro: Embrapa Agrobiologia, 2005. 58p.

MORDUE (LUNTZ), A. J.; MORGAN, E. D.; NISBET, A. J. Azadirachtin, a natural product in insect control. In: GILBERT, L. I.; IATROU, K.; GILL, S. S. (Ed.). Comprehensive molecular insect science. Amsterdam: Elsevier, p. 117-135. 2005.

OCAMPO, D. Y; OCAMPO, R. Bioactividad de La familia Annonaceae. Revista Universidad de Caldas, p. 135-155, 2006.

RODRIGUES, S. R. et al. Atividade inseticida de extratos etanólicos de plantas sobre Spodoptera frugiperda (J.E.Smith) (Lepitopdera: Noctuidae). Agrarian, v. 1, n. 1, p. 133-144, 2008.

RODRÍGUEZ, H. C.; VENDRAMIM, J. D. Avaliação da bioatividade de extratos aquosos de Meliaceae sobre Spodoptera frugiperda (J.E. Smith). Revista de Agricultura, v. 72, p. 305-318. 1997.

ROEL, A. R.; VENDRAMIM, J. D.; R. T. S. FRIGHETTO(4); NELSON FRIGHETTO(5). Efeito do extrato de acetato de etila de Trichilia pallida Swartz (Meliaceae) no desenvolvimento e sobrevivência da lagarta-docartucho. Bragantia, v. 59, p. 53-58, 2000. https://doi.org/10.1590/S0006-87052000000100009

SAS ${ }^{\circledR}$ Satatical Analysis System, SAS Institute Inc., 2003. 
SILVA, A. P. T. et al. Extrato etanólico da semente de aracitum (Annona coriacea) (Mart.) sobre a mortalidade da traça-do-tomateiro (Tuta absoluta). Resumos do V CBA - Manejo de Agroecossistemas Sustentáveis.

Revista Brasileira de Agroecologia, v. 2, p. 1150-1153. 2007.

SILVA, F. A. Z.; AZEVEDO, C. A. V. A. ASSISTAT, Assistência estatística. Versão 7,5 beta. 2009.

SALKELD, E. H.; SMITH, E. H.; The use and action of ovicides. Annual Review of Entomology, v. 11, p. 331-368, 1966. https://doi.org/10.1146/annurev.en.11.010166.001555

SOUZA, P. V.; SILVA, D. A.; JESUS, F. G.; ARAÚJO, M. S. Atividade inseticida de extratos hexânicos de Jatropha curcas L. sobre população de Plutella xylostella (L.) (Lepidoptera: Plutellidae). In: JORNADA DE PESQUISA E PÓS-GRADUAÇÃO E SEMANA NACIONAL DE CIÊNCIA E TECNOLOGIA, 6, 2011.

Anais... Goiânia: Universidade Estadual de Goiás. 2011. p.1-4.

SPIGNO, G.; TRAMELLI, L.; DE FAVERI, D. M. Effects of extraction time, temperature and solvent on concentration and antioxidant activity of grape marc phenolics. Journal of Food Engineering, v. 81, p. 200208. 2007. https://doi.org/10.1016/j.jfoodeng.2006.10.021

TORRECILLAS, S. M.; VENDRAMIM, J. D. Extratos aquosos de ramos de Trichilia pallida e o desenvolvimento de Spodoptera frugiperda em genótipos de milho. Scientia Agricola, v. 58, p. 27-31, 2001. https://doi.org/10.1590/S0103-90162001000100005

TORRES, A. L.; BOIÇA JUNIOR, A. L.; MEDEIROS, C. A. M.; BARROS, R. Efeito de extratos aquosos de Azadirachta indica, Melia azedarach e Aspidosperma pryrifolium no desenvolvimento e oviposição de Plutella xylostella. Bragantia, v. 65, p. 447-457, 2006. https://doi.org/10.1590/S0006-87052006000300011

TRINDADE, R. C. P.; MARQUES, I. M. R.; XAVIER, H. S.; OLIVEIRA, J. V. Extrato metanólico da amêndoa da semente de nim e a mortalidade de ovos e lagartas da traça-do-tomateiro. Scientia Agricola, v. 57, p. 407-413, 2000. https://doi.org/10.1590/S0103-90162000000300006

ZALUCKI M. Y.; SHABBIR A.; SILVA R.; ADAMSON D.; LIU SHU-SHENG L.; FURLONG M. J. Estimating the economic cost of one of the world's major insect pests, Plutella xylostella (Lepidoptera: Plutellidae): just how long is a piece of string? Journal of Economic Entomology, v. 105, n. 4, p. 1115-1129, 2012. https://doi.org/10.1603/EC12107 